\title{
Demonstration of novel innate immune cells in psoriasis
}

\author{
R Mak $^{1 *}$, C Hundhausen $^{1}$, E Botti ${ }^{2}$, U Laggner ${ }^{1}$, K Grys $^{1}$, I Tosi ${ }^{1}$, F O Nestle ${ }^{1}$ \\ From 5th European Workshop on Immune-Mediated Inflammatory Diseases \\ Sitges-Barcelona, Spain. 1-3 December 2010
}

\section{Introduction}

Psoriasis is a common chronic inflammatory skin disorder affecting $\sim 2 \%$ of the population worldwide. Both the adaptive and innate immune systems are important in driving the inflammation in genetically susceptible individuals. HLA-Cw6 located within the PSORS1 region on chromosome 6 is the most important psoriasis genetic marker. Correlations of HLA-C expression with different disease incidence and progression are described in the context of HLA-C's interaction with killer-like immunoglobulin receptors (KIR) expressed on innate immune effector cells; natural killer (NK) and natural killer T (NKT) cells.

\section{Aim}

We aimed to study the expression of KIR2DL1, the natural receptor for HLA-Cw6, in blood and skin of psoriasis patients and normal controls.

\section{Patients and methods}

Peripheral blood mononuclear cells (PBMCs) were isolated from blood samples of psoriasis patients $(n=46)$ and normal controls $(\mathrm{n}=10)$. The expression of skin homing markers and the cytokine production profile of peripheral KIR2DL1+ lymphocytes were further studied by flow cytometry analysis. Demonstration of KIR2DL1 cells in skin was performed with immunofluorescence (IF) staining and confocal imaging on frozen skin sections $(\mathrm{n}=3)$ and epidermal sheets $(\mathrm{n}=3)$.

\section{Results}

The majority of blood derived KIR2DL1+ lymphocytes are NK cells expressing CD56 with a small percentage of NKT cells expressing both CD56 and CD3. Peripheral KIR2DL1+ lymphocytes express a range of skin homing markers including CLA, CCR4, CCR6 and CCR10,

${ }^{1}$ St. John's Institute of Dermatology, London, UK

Full list of author information is available at the end of the article indicating their capacity to migrate from the periphery to skin. Furthermore, these cells are capable of producing different psoriasis relevant cytokines such as TNF $\alpha$ and IFN $\gamma$. IF staining demonstrated CD56+/CD3+ KIR2DL1+ cells in epidermis and dermal-epidermal junctions in both normal and psoriasis skin.

\section{Conclusion}

This is the first in situ demonstration of KIR2DL1+ cells in psoriasis skin. Their interaction with HLA-Cw6 expressing cells might affect the cytokine milieu in psoriasis and constitute a novel innate immune pathway important in psoriasis pathogenesis.

\section{Author details}

${ }^{1}$ St. John's Institute of Dermatology, London, UK. ${ }^{2}$ Dept. of Dermatology, University of Rome Tor Vergata, Rome, Italy.

Published: 25 November 2010

\section{doi:10.1186/1479-5876-8-S1-P18}

Cite this article as: Mak et al:. Demonstration of novel innate immune cells in psoriasis. Journal of Translational Medicine 2010 8(Suppl 1):P18.

Submit your next manuscript to BioMed Central and take full advantage of:

- Convenient online submission

- Thorough peer review

- No space constraints or color figure charges

- Immediate publication on acceptance

- Inclusion in PubMed, CAS, Scopus and Google Scholar

- Research which is freely available for redistribution 